ona częścią integralną tych obchodów w Chorągwi Ziemi Lubuskiej. W sesji uczestniczyła m.in. - obok przedstawicieli Komendy Chorągwi ZHP ZL i Komendy Hufca ZHP w Żarach - hm Dorota Kołakowska, szefowa obchodów 50-lecia NS w Kwaterze Głównej ZHP w Warszawie. Referentami byli w większości pracownicy naukowi (lub doktoranci) z ŁWSH i UAM w Poznaniu. Z pierwszym referatem na temat szans i barier społecznej integracji dzieci i młodzieży niepełnosprawnej wystąpiła prof. $Ł W S H$ Aleksandra Maciarz. Dr Edyta Głowacka-Sobiech, pracująca na co dzień w Zakładzie Historii Wychowania Uniwersytetu im. Adama Mickiewicza, przedstawiła tradycje harcerskiej pracy na rzecz osób niepelnosprawnych i dzieci wymagających specjalnej opieki wychowawczej z okresu sprzed 1939 roku. Doktorantka ZHW w UAM, Sylwia Hubicka, zaprezentowała natomiast działalność drużyn NS w Wielkopolsce. Dr Bożena Olszak-Krzyżanowska ukazała z kolei Drużynę NS jako formę uspołecznienia osób niepełnosprawnych intelektualnie. $\mathrm{O}$ metodzie harcerskiej w pracy z osobami niepełnosprawnymi, w świetle doświadczeń żarskich pedagogów specjalnych, mówił Tomasz Fetzki, doktorant ZHE UAM w Poznaniu, zarazem wykładowca ŁWSH, a na co dzień również nauczyciel Zespołu Szkół Specjalnych w Żarach. Z referatem na temat dzieci i młodzieży głuchej oraz niedosłyszącej w drużynach harcerskich wystąpiła hm Helena Stupkiewicz. O genezie NS i samych obchodach harcerskich 50-lecia Druźyn NS mówiła na zakończenie „części referatowej sesji”, wspomniana powyżej przedstawicielka KG ZHP, hm Dorota Kołakowska. W dyskusji swoimi refleksjami i wspomnieniami na temat działalności żarskich drużyn NS podzielił się m.in. hm. Mirosław Zengiel - Komendant Hufca ZHP im. II Armii Wojska Polskiego w Żarach.

Obradom i dyskusji podczas sesji towarzyszyła - przygotowana przez T. Fetzkiego wystawa, prezentująca „tradycje i dzień współczesny Harcerzy Nieprzetartego Szlaku na Ziemi Żarskiej".

Wiestaw Jamrożek

\title{
Konferencja naukowa w 450 rocznicę założenia Gdańskiego Gimna- zjum Akademickiego (1558-2008), Gdańsk 17 listopada 2008 r.
}

17 listopada 2008 r. miało miejsce ważne wydarzenie. $Z$ okazji 450 rocznicy powstania Gdańskiego Gimnazjum Akademickiego, staraniem prof. dr hab. Lecha Mokrzeckiego oraz Gdańskiej Wyższej Szkoły Humanistycznej, została odsłonięta tablica upamiętniająca budynek, w którym mieściło się gimnazjum (obecnie Muzeum Narodowe). Uroczystości towarzyszyła konferencja naukowa zorganizowana przez Gdańską Wyższą Szkołę Humanistyczną oraz Towarzystwo Historii Edukacji, stanowiąca kontynuację wcześniejszych sesji naukowych.

Obrady I części spotkania odbywały się w przepięknym budynku GWSH, a przewodniczył im prof. dr hab. Romuald Grzybowski. Po wprowadzeniu w tematykę, dokonanym przez prof. Lecha Mokrzeckiego, jej otwarcia dokonał Rektor GWSH prof. dr hab. Zbigniew Machaliński. 
Pierwszym prelegentem był prof. Lech Mokrzecki, który wygłosił referat dotyczący wybranych aspektów z dziejów Gdańskiego Gimnazjum Akademickiego. Przedstawił okoliczności powstania placówki oraz proces przekształcania szkoły w gimnazjum akademickie. Ponadto omówił poszczególne etapy funkcjonowania Gdańskiego Gimnazjum Akademickiego od XVI do XVIII w. Zarysował istotę akademickości szkoły oraz scharakteryzował działalność wybranych jej rektorów. Wystąpienie prof. dr hab. Edmunda Kotarskiego nawiązywało do poprzedniego. Autor zaprezentował XVII-wieczne biografie profesorów Gdańskiego Gimnazjum Akademickiego. Omówił schemat biografii wygłaszanych podczas uroczystości pogrzebowych, zwracając uwagę na szczegółowe przedstawianie rodowodu zmarłego, jego procesu wychowania, wykształcenia oraz pracy zawodowej. Prelegent zauważyl, że wiele biografów wzorowało się lub cytowało fragmenty (całość) autobiograficznych wypowiedzi.

Kolejne cztery referaty dotyczyły analizy przedmiotów wykładanych w Gdańskim Gimnazjum Akademickim. Nauczanie medycyny scharakteryzował dr Adam Szarszewski. Przedstawił metody nauczania podstaw medycyny, omówił działalność Katedry Anatomii i Medycyny, podkreślając zasługi kolejnych jej kierowników. Ponadto wskazał na związek medyków z chirurgami oraz ocenił jakość nauczania podstaw medycyny w Gdańskim Gimnazjum Akademickim. Znaczenie teologii w gdańskiej szkole przedstawił dr Sławomir Kościelak. Zwrócił uwagę na problematykę antykalwińską, antyireńską i antykatolicką występującą w tekstach m.in. J. Botsacka, A. Calowa, H. Nicolai przed i po Colloqium Charitativum. Natomiast dr Jacek Taraszkiewicz scharakteryzowal nauczanie prawa i historii, odwohując się do poglądów i metod m.in. J. Fabriciusa, J. Luleckiego i J. Pastoriusa. Mgr Mariusz Brodnicki dokonał analizy nurtów i okresów w nauczaniu filozofii i jej roli w XVI i XVII w. Omówił recepcję filozofii w duchu F. Melanchtona i Erazma z Rotterdamu oraz kształtowanie się arystotelizmu niescholastycznego. Życie i obyczaje studenckie w dawnym Gdańsku zaprezentował prof. dr hab. Edmund Kizik. Zapoznał słuchaczy m.in. z planami zajęć studentów, obowiązkowymi i fakultatywnymi wykładami, zwyczajami związanymi ze zdawaniem końcowych egzaminów, uczestnictwem (płatnym) w pogrzebach ważnych osobistości, przykładami przewinień i stosowanymi karami. Prof. dr hab. Kazimierz Puchowski w swoim wystąpieniu przedstawił działalność Gdańskiego Gimnazjum Akademickiego z szerszej perspektywy - umiejscawiając je na tle tendencji rozwojowych szkolnictwa katolickiego i protestanckiego w Prusach Królewskich. Zwrócił uwagę na ideały wychowania w szkołach katolickich i protestanckich, a także na zróżnicowany rozwój szkół jezuickich i Gdańskiego Gimnazjum Akademickiego. Wskazał na wysoki poziom nauczania i wychowania w placówkach protestanckich, na ich wspótpracę ze świeckimi władzami oraz na wpływ otwartej, nowoczesnej kultury protestanckiej zachodnioeuropejskiej.

Organizatorzy konferencji, nawiązując do świetnej tradycji sesji naukowych, poświęconych Gdańskiemu Gimnazjum Akademickiemu, nie tylko uczcili 450 rocznicę powołania gdańskiej szkoły, ale także, zapraszając do dysputy naukowej najznakomitszych badaczy problemu, zaprezentowali najnowsze, wieloaspektowe wyniki badań nad powstaniem, działalnością i rolą gdańskiej uczelni protestanckiej.

Katarzyna Kabacińska 